\title{
The Relationship between Transformational Leadership Style Job Satisfaction and the Effect of Organizational Commitment
}

\author{
Adel Mohamed Ali Shurbagi ${ }^{1}$ \\ ${ }^{1}$ Faculty of Economics, Azzaytuna University, Tarhunah, Libya \\ Correspondence: Adel Mohamed Ali Shurbagi, Faculty of Economics, Azzaytuna University, Tarhunah, Box \\ 82502 Tripoli, Libya. E-mail: Shurbagi@yahoo.com
}

Received: September 7, 2014

Accepted: October 8, 2014

Online Published: October 25, 2014

doi:10.5539/ibr.v7n11p126

URL: http://dx.doi.org/10.5539/ibr.v7n11p126

\begin{abstract}
It has been evidenced in the literature that transformational leadership style was a central feature of organizational performance while job satisfaction and organizational commitment have been theoretically and empirically linked to organizational effectiveness. It has also been argued that the relationship between transformational leadership style, job satisfaction and organizational commitment were differed some of the studies asserted that the relationship between these variables was positive relationship while other studies pointed out that the relationship between them were negative relationship. Furthermore, this study is attempted to investigate the relationship between transformational leadership, job satisfaction and organizational commitment and the effect of organizational commitment as a mediating variable on this relationship in Petroleum sector in Libya. Quantitative survey method was applied and four broadly hypothesized were tested with a sample of 280 employees from petroleum sector in Libya was selected to answer the questionnaire. SPSS software was used to analyze the data collected based on descriptive statistics (mean, standard deviation, percentage, Spearman Correlation and Multiple Regression). The empirical results indicated that organizational commitment effect the relationship between transformational leadership style and job satisfaction while, the relationship between transformational leadership style, job satisfaction and organizational commitment was positive significant relationship in petroleum sector in Libya.
\end{abstract}

Keywords: organizational commitment, transformational leadership style, job satisfaction, petroleum sector in Libya

\section{Introduction}

Libya is a member of the Organization of Petroleum Exporting Countries (OPEC) and holds the largest proven oil reserves in Africa. Libya has attracted hydrocarbon exploration since 1956, when the first wildcat oil well was drilled onshore in the Sirte Basin. Libya granted multiple concessions to Esso, Mobil, Texas Gulf, and others, resulting in major oil discoveries by 1959 . The government dominates Libya's economy through control of oil resources, which account for approximately $95 \%$ of export earnings, $75 \%$ of government receipts, and over $50 \%$ of GDP. The National Oil Corporation was established in 1970 to manage and controls Libya's petroleum sector, along with a number of smaller subsidiaries, which combined account for around half of the country's oil output. National Oil Corporation carries out exploration and production operations through its own affiliated companies, or in participation with other companies under service contracts or any other kind of petroleum investment agreements. This is in addition to marketing operations for oil and gas, locally as well as abroad. NOC has fully owned companies which carry out explorations, developments and production operations, in addition to local and international marketing companies (Sasi, 2008). The NOC is the biggest oil producer in Africa. Its mandate is to promote the Libyan economy by undertaking development, management and exploitation of oil resources as well as by participating in planning and executing the general oil policy of the state (National Oil Corporation, 2008). The choice of petroleum sector in Libya to investigate the effect of organizational commitment on the relationship between transformational leadership style and job satisfaction, because Libya is a member of organization of petroleum exporting countries (OPEC), this holds the largest proven oil reserves and the most important oil-producing countries in Africa and the world. The petroleum sector in Libya is very important because it is the backbone of Libyan economy. 


\subsection{Problem Statement}

The petroleum sector is the most important sector in Libya. Libya is one of the most important oil-producing countries in Africa and in the world, and that the interest in this sector is very important. Therefore, the relationship between transformational leadership style, job satisfaction and organizational commitment has attracted considerable interest from both academics and practitioners. Much of the interest on these variables is based on the results of the previous studies which have asserted that these concepts may have an impact on the organizations performance (Lok \& Crawford, 2001; Yousef, 2001; Shurbagi \& Zahari, 2012a).

Furthermore, Yet no study has been conducted to investigate the effect of organizational commitment on the relationship between transformational leadership style and job satisfaction as a mediating variable in the literature in general and in the petroleum sector in particular. This study, therefore, is unique as it will help to fill this gap in an effort to improve the understanding of the effect of organizational commitment on this relationship in Middle East in general and in Libyan setting in particular. Based on the foregoing, the effect of organizational commitment on the relationship between transformational leadership style and job satisfaction were not explored intensively enough in the literature.

\subsection{Research Objectives}

This paper has four objectives; the first aim is to determine the nature of the relationship between transformational leadership style and job satisfaction in petroleum sector in Libya. The second aim is to determine the nature of the relationship between transformational leadership style and organizational commitment in petroleum sector in Libya. The third aim is to determine the nature of the relationship between job satisfaction and organizational commitment in petroleum sector in Libya. The fourth aim is to determine the effect of organizational commitment on the relationship between transformational leadership style and job satisfaction in petroleum sector in Libya. Based on the research objectives stated, the following research questions were addressed:

Q1. Is there any relationship between transformational leadership style and job satisfaction in petroleum sector in Libya?

Q2. Is there any relationship between transformational leadership style and organizational commitment in petroleum sector in Libya?

Q3. Is there any relationship between job satisfaction and organizational commitment in petroleum sector in Libya?

Q4. Is there any mediating effect of organizational commitment on the relationship between transformational leadership style and job satisfaction in petroleum sector in Libya?

\section{Literature Review}

\subsection{Transformational Leadership}

The term of transformational leadership style was created by the politologist, Burns, in 1978, but was subsequently developed by Bass and colleagues, until it reached its current importance Avolio and Yammarino (2002) Bass (1985). Transformational leaders are leaders who motivate followers via inspiration. The followers are offered challenges and support personality development. Concentration on the intangible qualities, such as shared ideas, shared values and vision in an effort to build up good relationships inside the organization Bass (1985). According to Bass, Avolio, Jung and Berson (2003) the dimensions of transformational leadership style are as following:

a. Idealized influence (attributed) the leader shares risks with subordinates and is consistent in behaviour where ethics, principles, and values are concerned. The relationship between the leader and subordinates does not based on the formal institutional rules and regulations, rewards or punishments rather it is based on personal understanding.

b. Idealized influence (behaviour) emphasizes on a collective sense of mission and values, as well as acting upon these values Molero, Cuadrado, Navas and Morales (2007).

c. Inspirational motivation leaders motivate and inspire those around them by providing the meaning and challenge to the followers' work.

d. Intellectual stimulation leaders stimulate the followers' efforts as innovative and creative by questioning assumptions, reframing problems, and approaching old situations in new ways.

e. Individualized consideration leaders pay special attention to each individual's needs for achievement and 
growth by acting as a coach or mentor.

In the last three decades, academics and researchers have received increasing attention about the new paradigm called transformational leadership style where the interest of this study lays. Transformational leadership style is widely used in western and non-western countries. For instance, Suleiman, Azzawi and Jerjer (2003), AL-azmi (2006), Sabri, (2006) have pointed out that transformational leadership style has been widely used in different sectors in Arabic countries such as Iraq, Saudi Arabia, Jordan and United Arab Emirate. Many studies have also examined this relationship between the variables in the different sectors such as the public sector, health sector, industry sector, services sector, manufacturing sector and the education sector in Arabic countries and Western countries.

Therefore, the results between these variables differ and the leaders from these sectors follow transformational leadership style to manage their organizations Suleiman, Azzawi and Jerjer (2003), AL-azmi (2006), Ramey (2002). Less attention has been devoted in comprehending the links between transformational leadership style, job satisfaction, and the impact of organizational commitment on the relationship between these variables. Numerous studies in the area of job satisfaction have asserted that leadership style and organizational commitment have significant impact on job satisfaction (Lok \& Crawford 2001; Yousef, 2001; Ramey, 2002). However, most recently researchers have focused mainly on the subordinates' perspective and have proposed two main facets of leadership namely, transformational and transactional. This studies suggests that transformational leadership style, more than transactional leadership style, has a stronger positive effect on employees' attitudes towards their job, their job environment, and ultimately affects their work performance Bass (1985) Burns (1978). Thus, the study wishes to test transformational leadership theory at petroleum sector in Libya.

\subsection{Organizational Commitment}

The topic of organizational commitment has become immensely popular in the past two decades through interest of researchers and practitioners in the field of management (Mowday, et al. 1982; Meyer \& Allen, 1991). Organizational commitment has been researched in various contexts; including (a) Perceived Organizational Support (O’Driscoll \& Randall, 1999), (b) Performance Among Guest Workers (Shawa, et al. 2003), (c) Job Outcomes (Wasti, 2005), (d) Trust, Innovative Behavior (Lee, 2008), (e) Organizational Culture and Leadership Style (Lok \& Crawford, 1999) and (f) Job Satisfaction (Lim, 2010; Shurbagi \& Zahari, 2013b). Some of these studies pointed out that organizational commitment have a positive relationship with these variables.

\subsubsection{Definition of Organizational Commitment}

Organizational commitment, like most other concepts in social sciences, has no single or unique definition. It has been defined differently by different authors. For instance, (Kanter, 1968) described 'cohesion commitment' as 'the attachment of an individual's fund of affectivity and emotion to the group'. While (Buchanan, 1974) conceptualized commitment as a partisan, affective attachment to the goals and values of the organization to one's role in relation to the goals and values, and to the organization for its own sake, apart from its purely instrumental worth. Porter, et al. (1974) defined organizational commitment as the strength of an individual's identification with and involvement in a particular organization. Such commitment can generally be characterized by at least three factors:

a. A strong belief in and acceptance of the organization's goals and values.

b. A willingness to exert considerable effort on behalf of the organization.

c. A definite desire to maintain organizational membership.

O'Reilly and Chatman (1986) defined commitment as the psychological attachment felt by the person for the organization, reflecting the degree to which the individual internalizes or adopts the characteristics or perspectives of the organization. Mathieu and Zajac, (1990) from their view defined organizational commitment as 'a bond or linking of the individual to the organization'. On the other hand, Meyer and Allen, (1984), building to Porter, et al. (1974), definition has been divide the concept of organizational commitment into three components and defined organizational commitment in terms of affective, continuance, and normative.

Affective commitment refers to the employee's emotional attachment to, identification with, and involvement in the organization.

Continuance commitment refers to an awareness of the costs associated with leaving the organization.

Normative commitment reflects a feeling of obligation to continue employment.

In Meyer and Allen, (1984) definitional approach, the three components of organizational commitment are 
components rather than types. Meyer and Allen, (1984) noted the bases are conceptually mutually exclusive.

\subsubsection{Meyer and Allen Model (1991)}

The three components or dimensions of commitment was introduced by Meyer and Allen, (1984) this model was rooted in earlier approaches to organizational commitment which has been done by (Becker, 1960 and Porter, et, al. 1974). Meyer and Allen, (1984) asserted that these three dimensions of commitment is a psychological state which describe as characterizes the employee's relationship with the organization, and the implications for the decision to continue or discontinue membership in the organization. However, it is clear that the nature of the psychological states differ. These three dimensions are affective, continuance and normative describe as follow.

a. Affective commitment refers to the employee's emotional attachment to, identification with, and involvement in the organization. Employees with a strong affective commitment continue employment with the organization because they want to do so (Meyer \& Allen, 1984). The most important reason for wanting to remain with the organization is related to the ability of individuals to satisfy their needs at work (Hackman \& Oldham, 1976). Allen and Meyer (1990) have been suggested that the antecedents of affective attachment to the organization divide into four categories: personal characteristics, job characteristics, work experiences and structural characteristics.

b. Meyer and Allen, (1984) proposed the continuance dimension as a better representation of Becker's side-bet approach. It refers to an awareness of the costs associated with leaving the organization. Employees whose primary link to the organization is based on continuance commitment remain because they need to do so. It is related to the benefits associated with staying versus the personal costs associated with leaving such as pensions, seniority, social status, and access to social networks that bind him or her to the organization. These interests would be at risk if the individual left the organization (Dawleya et al., 2005; Shahnawaz \& Juyal, 2006).

c. Normative commitment was defined as a feeling of obligation to continue employment. Employees with a high level of normative commitment feel that they ought to remain within the organization (Allen and Meyer, 1990). Individuals with high normative commitment stay in the organization because they believe it is the right and moral thing to do. Stated differently, they would feel guilty if they left the organization and stay, even if they had to reject better alternatives (Felfea \& Yan, 2009). Normative commitment is affected in the main by socialization or culture prior to entry into an organization also would be influenced by the individual's experiences both prior to familial or cultural socialization and following organizational socialization entry into the organization (Wiener, 1982; Cohen, 2007).

The three dimensions were characterized as a "three component conceptualization of Organizational Commitment" and were described as components rather than types commitment that is, employees can experience each of these psychological states to varying degrees (Allen \& Meyer, 1990; WeiBo et al. 2010). Based to the literature the approach of Meyer and Allen, (1984) became the dominant one to the study of commitment (Wiener, 1982; Cohen, 2007).

\subsection{Job Satisfaction}

Job satisfaction has been a phenomenon of intense interest among practitioners and researchers for several decades (Cranny, et al. 1992; Hwang \& Chi, 2005; Locke, 1976; Spector, 1997). Many different definitions have been put, for instance, some definitions focus on the job itself, while others include all the job-related factors. Practitioners and researchers have defined satisfaction as positive feelings or aggressive responses; whereas others have defined it as the gap between the expected gain and the actual gain. Reference (Spector 1985) views job satisfaction as a cluster of evaluative feelings about the job.

\subsubsection{Determinants of Job Satisfaction}

According to the literature on the job satisfaction there are numerous factors that influence job satisfaction. (Worrell, 2004), divided these factors into three groups of which the demographic data which includes age, gender, and race; the intrinsic factors that include achievement, recognition, work itself, responsibility, advancement and growth; and the extrinsic factors that include company policy, supervision, relationship with boss, work conditions, relationship with peers and salary. Both the intrinsic factors and extrinsic factors are related to the Two Factor Theory by Herzberg.

In the last three decades, academics and researchers have received increasing attention to investigate the relationship between leadership behavior, job satisfaction, and organizational commitment most of these studies have investigated the relationship between these variables independently (Williams \& Hazer, 1986; Yousef, 2000; Lok \& Crawford, 2001; Lim, 2010). Numerous of these studies in the area of organizational behavior asserted that the relationship between transformational leadership style, job satisfaction and organizational 
commitment was significant and positive relationship (Yousef, 1998; Chen \& Francesco, 2000; Lok \& Crawford 2001; Xenikou \& Simosi, 2006; Rad \& Yarmohammadian, 2006, Hu, et al., 2009; Shurbagi \& Zahari, 2012b).

On the other hand, Yiing and Zaman Ahmad, (2009), pointed out that the relationship between job satisfaction and organizational commitment was negative relationship in Education sector in Malaysia. Yousef, (2000) and Lim, (2010) further suggested that job satisfaction and organizational commitment have been theoretically and empirically linked to organizational effectiveness these finding asserted by Lok and Crawford, (2004) who confirmed that organizational commitment and job satisfaction can be the major determinants of organizational performance and effectiveness. In addition, Oluseyi and Ayo (2009) pointed out that leadership is a central feature of organizational performance. This is an essential part of management activities of people and directing their efforts towards the goals and objectives of the organization.

On the other hand, Perryer and Jordan (2005) confirmed that organizational commitment was an important employee attribute from the organization's perspective. Several studies have found relationships between high-commitment human resource policies and positive organizational outcomes such as productivity, quality, and profitability. Organizational commitment has been studied in relation to employee performance there is still considerable controversy surrounding the precise nature of the relationship. While there is some evidence to suggest that organizational commitment is a mediating variable between leadership style and performance.

In brief, some scholars have tested the mediating and moderating impact of organizational culture and organizational commitment on the relationship between leadership behaviour, job performance and job satisfaction the results of these studies are not exactly consistent. For instance, Chen (2004) confirmed that the effect of leadership behaviours on organizational commitment was to be differed by organizational culture. Therefore, organizational commitment as a mediating effort in the relationship between transformational leadership behaviours and job satisfaction was found to be not influenced by organizational culture. The findings asserted that organizational commitment mediates the relationship between transformational leadership behaviours and job performance. Furthermore, Lok and Crawford, (2004) revealed that organizational commitment, and job satisfaction influenced by differ types of organizational cultures while leadership style may impact job satisfaction and commitment. Also Crawford, (2004) has been confirmed that organizational culture and leadership styles were important organizational antecedents of job satisfaction and commitment.

On the other hand, Yiing and Zaman Ahmad, (2009) investigated the moderating effects of organizational culture on the relationship between leadership behaviour and organizational commitment and between organizational commitment and job satisfaction and performance. Yiing and Zaman Ahmad, (2009) pointed out that organizational culture has significant moderating effects on the relationship between leadership behaviours and organizational commitment while the relationship between organizational commitment job satisfactions was negative significant relationship. However, the effect of organizational commitment as a mediating variable on the relationship between transformational leadership style and job satisfaction were not explored intensively enough in the literature in general and in petroleum sector in particular. Consequently, study that examines the complex relationships and interaction between these variables such as transformational leadership style, job satisfaction and organizational commitment and the effect of organizational commitment on this relationship will be of value to management theorists and practitioners. Furthermore, the current study wishes to test the relationship between transformational leadership style, job satisfaction, organizational commitment and the effect of organizational commitment on this relationship in petroleum sector in Libya.

\section{Research Methodology}

\subsection{Research Hypotheses}

Based on the literature review, research questions and research objectives the hypotheses of the study are as follow:

H1. There is a relationship between transformational leadership style and job satisfaction in petroleum sector in Libya.

H2. There is a relationship between transformational leadership style and organizational commitment in petroleum sector in Libya.

H3. There is a relationship between job satisfaction and organizational commitment in petroleum sector in Libya.

H4. Organizational commitment has significant effect on the relationship between transformational leadership style and job satisfaction in petroleum sector in Libya. 


\subsection{Instruments Measurement}

To gather research data in the current study, questionnaire is preferred due to its ability to collect data from respondents within a limited time frame. The instrument consisted four parts such as demographic variables, transformational leadership style, job satisfaction, and organizational commitment. Three instruments were used to measure the variables of the study. These instruments are as following:

1). Multifactor Leadership Questionnaire (MLQ) was used to measure transformational leadership style Avolio and Bass (2004). This instrument has been revised several times and is widely used to measure transformational leadership style in different countries in the world and the validity and reliability of this scale have been established through previous research Hartog, Muijen and Koopman (1997). Participants were asked to describe their supervisor's leadership behaviour on 20 items based on transformational leadership. A five-point Likert scale was used with the responses ranging from ( $1=$ not at all; to $5=$ frequently, if not always). In the (MLQ) transformational leadership style is measured via the use of the five dimensions of transformational leadership style. The dimensions were measured by four items for each, such as intellectual stimulation, idealized influence (behaviour), idealized influence (attributed) inspirational motivation, and individualized consideration.

2). Three Components Organizational Commitment Questionnaire (TCOCQ) developed by (Allen and Meyer, 1990) instrument for the multidimensional organizational commitment was adopted for this study to measure organizational commitment. The instrument measures the three dimensions of organizational commitment includes items that measure affective, continuance and normative commitment. There are 24 items in the scale, each dimension of organizational commitment (affective, continuance and normative) has 8 items. A five-point Likert scale will be used with responses ranging from ( $1=$ strongly disagree; to $5=$ strongly agree).

3). The Job Satisfaction Survey (JSS) developed by Spector (1997) includes 20 items was used to measure five facets of job satisfaction. The facets were measured by four items for each, such as supervision, benefits, rewards, operating procedure and co-workers satisfaction. A five-point Likert scale will be used with responses ranging from ( $1=$ strongly disagree; to $5=$ strongly agree).

Therefore, the validity and reliability of the instruments which use in this study such as The Multifactor Leadership Questionnaire (MLQ), The Job Satisfaction Survey (JSS) and Three Components Organizational Commitment Questionnaire (TCOCQ) scales have been established through previous researches and the Cranach's Alpha coefficient of the instruments were above 0.70 (Allen \& Meyer, 1990; Spector, 1997; Lim, 2010; Shurbagi \& Zahari, 2013b; Shurbagi, 2014a). In the current study the Cronbach's Alpha coefficient of transformational leadership style, job satisfaction and organizational commitment were $(0.92 ; 0.82$; and 0.74$)$ respectively.

\subsection{Participants}

To investigate the effect of the organizational commitment on the relationship between transformational leadership style and job satisfaction in petroleum sector in Libya, out of (280) questionnaires were distributed with (250) returning. Of the (250) that returned, (23) questionnaires were rejected, due to insufficient data, resulting in (227) usable questionnaires yielding a response rate of $81 \%$. The stratified sample sampling was used in this study and the data were then analyzed using Statistical Package for Social Sciences (SPSS). Details are given in table 1 .

Table 1. Questionnaires distributed

\begin{tabular}{ccccc}
\hline Questionnaires distributed & Questionnaires returned & Questionnaires rejected & Questionnaires usable & Percent $\%$ \\
\hline 280 & 250 & 23 & 227 & 81 \\
\hline
\end{tabular}

\section{Empirical Results}

Data was analyzed through descriptive statistical methods with mean, standard deviation, percentage, Correlation Coefficient, Linear, and Multiple Regression. Table 2.1 contained profile of the respondents of the study. From the table 2.1 it was obvious that the respondents between 36-45 years constitute majority of respondents with $104(45.8 \%)$ of the total of respondents while the least respondents with age range goes to those with less than 25 years 6 respondents $(2.6 \%)$. As mentioned earlier, the respondents for this study are employees in gas and oil industry in Libya, the majority of respondents hold Master degrees 77 (33.9\%), while 15 respondents (6.6\%) completed their $\mathrm{PhD}$ degree. 158 (69.6\%) of the respondents were married while only 69 respondents (30.4\%) 
were single. From total of 227 respondents from gas and oil industry in Libya indicate that, 168 of them (74\%) were male while the remaining was female. 89 respondents $(39.2 \%)$, reported that their income was 1101-1500 DL monthly and only two respondents $(0.9 \%)$ their salary was more than 2300 DL monthly. From table 1.2 it can be seen that 46 of respondents (20.3\%) have working experiences with gas and oil industry in Libya for 11-15 years, only 25 of respondents (11.0\%) have working experiences in oil and gas industry in Libya for 1-5 years. Finally, the majority of respondents with 130 (57.3\%) of the total of respondents their boss's function was coordinator. This is followed by 63 respondents $(27.8 \%)$ who their boss's function was director. On the other hand, only 34 respondents (15\%) their boss's function was observer. All this information has given in Table 2.

Table 2. Profit of the respondents

\begin{tabular}{|c|c|c|}
\hline Contents & Frequency & Percent $\%$ \\
\hline \multicolumn{3}{|l|}{ Age } \\
\hline$<25$ years & 6 & 2.6 \\
\hline $26-35$ years & 53 & 23.3 \\
\hline $36-45$ years & 104 & 45.8 \\
\hline 46 - 55 years & 51 & 22.5 \\
\hline$>55$ years & 13 & 5.7 \\
\hline \multicolumn{3}{|l|}{ Educational level } \\
\hline Primary School & 10 & 4.4 \\
\hline Secondary School & 56 & 24.7 \\
\hline Degree & 69 & 30.4 \\
\hline Master Degree & 77 & 33.9 \\
\hline $\mathrm{PhD}$ & 15 & 6.6 \\
\hline \multicolumn{3}{|l|}{ Marital status } \\
\hline Single & 69 & 30.4 \\
\hline Married & 158 & 69.6 \\
\hline \multicolumn{3}{|l|}{ Gender } \\
\hline Male & 168 & 74 \\
\hline Female & 59 & 26 \\
\hline \multicolumn{3}{|l|}{ Income } \\
\hline$<700 \mathrm{DL}$ & 23 & 10.1 \\
\hline 701-1100 DL & 48 & 21.1 \\
\hline 1101-1500 DL & 89 & 39.2 \\
\hline $1501-1900 \mathrm{DL}$ & 58 & 25.6 \\
\hline 1901-2300 DL & 7 & 3.1 \\
\hline$>2300 \mathrm{DL}$ & 2 & 0.9 \\
\hline \multicolumn{3}{|c|}{ Experience of Working } \\
\hline $1-5$ years & 25 & 11 \\
\hline $6-10$ years & 45 & 19.8 \\
\hline $11-15$ years & 46 & 20.3 \\
\hline $16-20$ years & 35 & 15.4 \\
\hline 21- 25 years & 33 & 14.5 \\
\hline$>25$ years & 43 & 18.9 \\
\hline \multicolumn{3}{|c|}{ Function of your boss } \\
\hline Coordinator & 130 & 57.3 \\
\hline Director & 63 & 27.8 \\
\hline Observer & 34 & 15 \\
\hline
\end{tabular}


Table 3 provided the percentages, means, and standard deviations related to the perceptions of respondents of the petroleum sector in Libya about transformational leadership, job satisfaction and organizational commitment in their organization. According to table 3 the means of dimensions of transformational leadership such as intellectual stimulation, idealized influence behaviour, idealized influence attributed, inspirational motivation and individualized consideration were $(3.25,3.48,3.50,3.38$ and 3.10) respectively and the standard deviations of them were $(0.849,0.866,0.881,0.786$ and 0.983$)$.

on the other hand, the means of facets of job satisfaction such as supervision satisfaction, benefits satisfaction, rewards satisfaction, operation procedure satisfaction and co-workers satisfaction were $(3.24,2.79,2.94,2.90$ and 3.05), and the standard deviations of them were $(0.82,0.88,0.92,0.81$ and 0.83$)$ respectively.

On the other hand, according to table 3 the means of affective, continuance and normative commitment were $(2.93,2.76$ and 2.83$)$ respectively, while the standard deviations of them were $(0.83,0.60$ and 0.80$)$ respectively. Table 3.1 summarizes the mean and standard deviation of these variables.

Table 3. Mean and standard deviation

\begin{tabular}{lcc}
\hline Variables \& Dimensions & M & SD \\
\hline Intellectual stimulation (IS) & 3.25 & 0.849 \\
Idealized influence (behaviour) (IIB) & 3.48 & 0.866 \\
Idealized influence (attributed) (IIA) & 3.50 & 0.881 \\
Inspirational motivation (IM) & 3.38 & 0.786 \\
Individualized consideration (IC) & 3.10 & 0.983 \\
Transformational Leadership (TL) & $\mathbf{3 . 3 4}$ & $\mathbf{0 . 7 6 2}$ \\
\hline Supervision Satisfaction (SS) & 3.24 & 0.825 \\
Benefits Satisfaction (BS) & 2.79 & 0.881 \\
Rewards Satisfaction (RS) & 2.94 & 0.928 \\
Operation Procedure Satisfaction (OPS) & 2.90 & 0.815 \\
Co-Workers Satisfaction (CWS) & 3.05 & 0.837 \\
Job Satisfaction (JS) & $\mathbf{2 . 9 8}$ & $\mathbf{0 . 6 5 7}$ \\
\hline Affective Commitment (AC) & 2.93 & 0.831 \\
Continuance Commitment (CC) & 2.76 & 0.606 \\
Normative Commitment (NC) & 2.83 & 0.801 \\
Organizational Commitment (OC) & $\mathbf{2 . 8 4}$ & $\mathbf{0 . 6 1 4}$ \\
\hline
\end{tabular}

Cronbach Coefficient Alpha was used to test the reliability of the instruments Sekaran, (2005) pointed out that Cronbach Coefficient Alpha of 0.70 or more are considered good. The Cronbach's alpha reliability coefficients for transformational leadership style, job satisfaction, and organizational commitment were $(0.92,0.82$ and 0.74$)$ respectively. Based on the Cronbach Alpha values for transformational leadership style, job satisfaction and organizational commitment the instruments are reliable to measure the variables of the study.

To study the correlation between variables, spearman correlation coefficient was selected to investigate the relationship between these variables. Table 4 below shows that there is a high and significant correlation among the variables of the study. A robust correlation between transformational leadership style and job satisfaction of 0.569 and is significant at .01 level. A strong relationship was identified between transformational leadership style and organizational commitment with a correlation coefficient of 0.560 significance at .01 level. While the correlation between job satisfaction and organizational commitment was 0.619 at the same level of significance. Table 4 summaries the results of correlation between the variables of the study. 
Table 4. Correlation between variables of the study

\begin{tabular}{lccc}
\hline & Transformational Leadership & Job Satisfaction & Organizational Commitment \\
\hline Transformational Leadership & 1 & $0.569^{* *}$ & $0.560^{* *}$ \\
Job Satisfaction & & 1 & $0.619^{* *}$ \\
Organizational Commitment & & & 1 \\
\hline
\end{tabular}

On the same line, based on table 5.1 the result of correlation the relationship between dimensions of transformational leadership style, facets of job satisfaction and component of organizational commitment was positive and significant relationship at 0.01 level. Therefore, the highest correlation between dimensions of transformational leadership style and facets of job satisfaction was found between operation procedure satisfaction and individualized consideration, $r=0.590$ and the lowest correlation was found between benefits satisfaction and inspiration motivation, $r=0.168$. Besides that, the highest correlation between facets of job satisfaction and component of organizational commitment was found between operation procedure satisfaction and normative commitment, $\mathrm{r}=0.574$ and the lowest correlation between them was found between supervision satisfaction and affective commitment, $r=0.195$.

On the other hand, the highest correlation between dimensions of transformational leadership style and component of organizational commitment was found between idealized influence behaviour and normative commitment, $r=0.585$ and the lowest correlation was found between intellectual stimulation and affective commitment, $r=0.209$.

Based on the results of the correlation between the variables of the study and their dimensions it could be concluded that the relationship between the variables of the study such as transformational leadership style, job satisfaction and organizational commitment was significant positive relationship. In addition, these results consistent with previous studies which concluded that the relationship between transformational leadership style, job satisfaction and organizational commitment was positive and significant relationship. Table 5summarizes the results of correlation.

Table 5. Correlation between dimensions of the variables

\begin{tabular}{|c|c|c|c|c|c|c|c|c|c|c|c|c|c|}
\hline & IS & IIB & IIA & IM & IC & SS & BS & RS & OPS & CWS & AOC & $\mathrm{COC}$ & NOC \\
\hline IS & 1.000 & $0.655^{* *}$ & $0.623 * *$ & $0.606^{* *}$ & $0.680^{* * *}$ & $0.423 * *$ & $0.218^{* *}$ & $0.352^{* *}$ & $0.482 * *$ & $0.436^{* *}$ & $0.209^{* *}$ & $0.412 * *$ & $0.482 * *$ \\
\hline IIB & & 1.000 & $0.846^{* *}$ & $0.657^{* *}$ & $0.773 * *$ & $0.471 * *$ & $0.222 * *$ & $0.240 * *$ & $0.547 * *$ & $0.482^{* *}$ & $0.321 * *$ & $0.478 * *$ & $0.585^{* *}$ \\
\hline IIA & & & 1.000 & $0.662^{* *}$ & $0.764 * *$ & $0.448^{* *}$ & $0.270^{* *}$ & $0.202^{* *}$ & $0.470 * *$ & $0.407^{* *}$ & $0.223^{* *}$ & $0.407 * *$ & $0.545^{* *}$ \\
\hline $\mathrm{IM}$ & & & & 1.000 & $0.708^{* *}$ & $0.364 * *$ & $0.168^{*}$ & $0.275^{* *}$ & $0.464 * *$ & $0.349 * *$ & $0.331^{* *}$ & $0.317 * *$ & $0.440 * *$ \\
\hline IC & & & & & 1.000 & $0.479^{* *}$ & $0.260^{* *}$ & $0.312^{* *}$ & $0.591 * *$ & $0.463^{* *}$ & $0.296^{* *}$ & $0.400 * *$ & $0.566^{* *}$ \\
\hline SS & & & & & & 1.000 & $0.350^{* *}$ & $0.254 * *$ & $0.399 * *$ & $0.361^{* *}$ & $0.195^{* *}$ & $0.266 * *$ & $0.345^{* *}$ \\
\hline BS & & & & & & & 1.000 & $0.252^{* * *}$ & $0.456^{* *}$ & $0.411 * *$ & $0.353^{* *}$ & $0.242 * *$ & $0.413 * *$ \\
\hline RS & & & & & & & & 1.000 & $0.327 * *$ & $0.384 * *$ & $0.260 * *$ & $0.214 * *$ & $0.269 * *$ \\
\hline OPS & & & & & & & & & 1.000 & $0.623^{* *}$ & $0.478^{* *}$ & $0.417 * *$ & $0.574 * *$ \\
\hline CWS & & & & & & & & & & 1.000 & 0.436 ** & $0.454 * *$ & $0.557^{* *}$ \\
\hline $\mathrm{AOC}$ & & & & & & & & & & & 1.000 & $0.429 * *$ & $0.443 * *$ \\
\hline $\mathrm{COC}$ & & & & & & & & & & & & 1.000 & $0.648 * *$ \\
\hline NOC & & & & & & & & & & & & & 1.000 \\
\hline
\end{tabular}

\section{Hypotheses Testing}

To test the effect of organizational commitment on the relationship between transformational leadership style and job satisfaction in petroleum sector in Libya Multiple Linear Regression Analysis was used. As shown in Table 6.1 the R Square of 0.47 , means that the data used in the sample accounts for about $47 \%$ of the relationship between transformational leadership, organizational commitment and job satisfactions in the population. The 
probability value obtained is less than the predetermined alpha value (p-value $<.05$ ). There exists adequate evidence to show that organizational commitment has a significant effect on the relationship between transformational leadership and job satisfaction in petroleum sector in Libya. In addition, organizational commitment contains significant predictors in estimating the relationship between transformational leadership style and job satisfaction. From the results of the regression analysis it can be concluded that organizational commitment has an effect on the relationship between transformational leadership style and job satisfaction. Table 6 summarizes the results of multiple regression analysis.

Table 6. Multiple regression analyses between varailes of the study

\begin{tabular}{|c|c|c|c|c|c|}
\hline $\mathbf{R}$ & \multicolumn{2}{|c|}{ R Square } & Adjusted R Square & \multicolumn{2}{|c|}{ Std. Error of the Estimate } \\
\hline \multirow[t]{3}{*}{0.687} & \multicolumn{2}{|c|}{0.472} & 0.467 & \multicolumn{2}{|c|}{0.468} \\
\hline & \multicolumn{2}{|c|}{ Unstandardized } & Standardized & $\mathbf{t}$ & Sig. \\
\hline & B & Std. Error & Beta & & \\
\hline (Constant) & 0.757 & 0.161 & & 4.709 & 0.000 \\
\hline Organizational commitment & 0.365 & 0.063 & 0.350 & 5.828 & 0.000 \\
\hline Transformational leadership & 0.354 & 0.050 & 0.421 & 7.016 & 0.000 \\
\hline
\end{tabular}

\section{Conclusion, Recommendations \& Limitations}

The present sought to explain the relationship between transformational leadership, job satisfaction and organizational commitment and the effect of organizational commitment on this relationship between these variables in petroleum sector in Libya. It found that there is a positive relationship between these variables and organizational commitment effect the relationship between transformational leadership and job satisfaction. The results of the current study are mostly consistent with the previous studies except the result of the effect of organizational commitment which did not explore in the literature. However, there are possible limitations in the relation to the research design of this study. For instance, other leadership styles, such as transactional, and laissez-faire were not investigated, as these variables might also have a relationship with job satisfaction and organizational commitment.

In addition, the outcomes of leaders in the current study were not included in the scope of this research and these factors may also have a relationship with job satisfaction and organizational commitment and may have an effect on organizational performance in the public and private sectors. Therefore, further study is recommended using other leadership styles so that leaders can fully understand and appreciate the appropriate methodology that will effectively enhance performance in specific public sector organizations. In addition, it is recommended that similar studies could be carried out in the private sector or in both sectors (public and private) to determine whether the relationship between transformational leadership, job satisfaction and organizational commitment varies in the different sectors. This could help to clarify the differences between the public and private sector. It is also to be noted that the study was carried out within a small geographic area and this may have affected the validity of generalization. Further research may therefore be needed in a wider scope, such as at state or national level. Similarly, the outcomes of leaders in the current study were not in the scope of this research; therefore future researchers could investigate the outcomes of leaders in both the public and private sectors.

\section{References}

AL-azmi, M. B. (2006). Transference leadership and its relation with managerial creative: surveying study on civil employees department ministry of interior.

Allen, N. J., \& Meyer, J. P. (1990). The measurement and antecedents of affective, continuance and normative commitment to the organization. Journal of Occupational Psychology, 63, 1-18. http://dx.doi.org/10.1111/j.2044-8325.1990.tb00506.x

Avolio, B. J., \& Bass, B. M. (2004). Multifactor leadership questionnaire: manual and sampler set. Mind Garden, Inc.

Avolio, B. J., \& Yammarino, F. J. (2002). Transformational and charismatic leadership: The road ahead. New York: Erlbaum.

Bass, B. M. (1985). Leadership and performance beyond expectations. Free Press. 
Bass, B. M., Avolio, B. J., \& Jung, D. I. (2003). Berson Y. Predicting unit performance by assessing transformational and transactional leadership. Journal of Applied Psychology, 88(2), 207. http://dx.doi.org/10.1037/0021-9010.88.2.207

Becker, H. S. (1960). Notes on the Concept of Commitment. American Journal of Sociology, 66, 32-42. http://dx.doi.org/10.1086/222820

Buchanan, B. (1974). Building organizational commitment: The socialization of managers in work organizations. Administrative Science Quarterly, 19, 533-546. http://dx.doi.org/10.2307/2391809

Burns, J. M. (1978). Leadership New York. NY: Harper and Row Publishers.

Chen, L. Y. (2004). Examining the Effect of Organization Culture and Leadership Behaviors on Organizational Commitment, Job Satisfaction, and Job Performance. The Journal of American Academy of Business, 432-438.

Chen, Z. X., \& Francesco., A. M. (2000). Employee demography, organizational commitment, and turnover intentions in China: do cultural differences matter? Human Relations, 53(6), 869-887. http://dx.doi.org/10.1177/0018726700536005

Cohen, A. (2007). Commitment before and after: An evaluation and reconceptualization of organizational commitment. Human Resource Management Review, 17, 336-354. http://dx.doi.org/10.1016/j.hrmr.2007.05.001

Cranny, C. J., Smith, P. C., \& Stone, E. (1992). Job satisfaction: How people feel about their jobs and how it affects their performance. New York: Lexington.

Dawleya, D. D., Stephensa, D. R., \& Stephensb, B. D. (2005). Dimensionality of organizational commitment in volunteer workers: Chamber of commerce board members and role fulfillment. Journal of Vocational Behaviour, 67, 511-525. http://dx.doi.org/10.1016/j.jvb.2004.09.001

Felfea, J., \& Yan, H. W. (2009). The impact of workgroup commitment on organizational citizenship behaviour, absenteeism and turnover intention: the case of Germany and China. Asia Pacific Business Review, 15(3), 433-450. http://dx.doi.org/10.1080/13602380802667411

Hackman, J. R., \& Oldham, G. R. (1976). Motivation through the design of work: Test of a theory. Organizational Behavior and Human Performance, 16, 250-279. http://dx.doi.org/10.1016/0030-5073(76)90016-7

Hartog, D. N., Muijen, J. J., \& Koopman, P. L. (1997). Transactional versus transformational leadership: An analysis of the MLQ. Journal of Occupational and Organizational Psychology, 70(1), 19-34. http://dx.doi.org/10.1111/j.2044-8325.1997.tb00628.x

Hu, Y. J., Yang, F. Y., \& Islam, M. (2009). Leadership behavior, satisfaction, and the balanced scorecard approach: An empirical investigation of the manager-employee relationship at retail institutions in Taiwan. International Journal of Commerce and Management, 20(4), 339-356. http://dx.doi.org/10.1108/10569211011094659

Hwang, I. S., \& Chi, D. J. (2005). Relationships among internal marketing, employee job satisfaction and international hotel performance: An empirical study. International Journal of Management, 22(2), 285-293.

Kanter, R. M. (1968). Commitment and social organization: A study of commitment mechanisms in utopian communities. American Sociological Review, 33, 499-517. http://dx.doi.org/10.2307/2092438

Lee, S. H. (2008). The Effect of Employee Trust and Commitment on Innovative Behavior in the Public Sector: An Empirical Study. International Review of Public Administration, 13(1), 27-46. http://dx.doi.org/10.1080/12294659.2008.10805110

Lim, T. (2010). Relationships among organizational commitment, job satisfaction, and learning organization culture in one Korean private organization. Asia Pacific Education Review, 11, 311-320. http://dx.doi.org/10.1007/s12564-010-9087-z

Locke, E. A. (1976). The nature and causes of job satisfaction. In M. D. Dunnette (Ed.), Handbook of industrial and organizational psychology. Chicago, IL: Rand McNally College Publishing.

Lok, P., \& Crawford, J. (2001). Antecedents of organizational commitment and the mediating role of job satisfaction. Journal of Managerial Psychology, 16(8), 594-613. http://dx.doi.org/10.1108/EUM0000000006302 
Lok, P., \& Crawford, J. (2004). The effect of organizational culture and leadership style on job satisfaction and organizational commitment. Journal of Management Development, 23(4), 321-335. http://dx.doi.org/10.1108/02621710410529785

Lok, P., \& Crawford, J. (1999). The relationship between commitment and organizational culture, subculture, leadership style and job satisfaction in organizational change and development. Leadership and Organization Development Journal, 20(7), 365-373. http://dx.doi.org/10.1108/01437739910302524

Mathieu, J. E., \& Zajac, D. M. (1990). A review and meta-analysis of the antecedents, correlates, and consequences of organizational commitment. Psychological Bulletin, 108(2), 171-194. http://dx.doi.org/10.1037/0033-2909.108.2.171

Meyer, J. P., \& Allen, N. J. (1991). A Three-Component Conceptualization of Organizational Commitment. Human Resource Management Review, 1(1), 61-89. http://dx.doi.org/10.1016/1053-4822(91)90011-Z

Meyer, P. J., \& Allen, J. N. (1984). Testing the side-bet theory of organizational commitment: Some methodological considerations. Journal Applied Psychology, 69, 372-378. http://dx.doi.org/10.1037/0021-9010.69.3.372

Molero, F., Cuadrado, I., Navas, M., \& Morales, J. (2007). Relations and effects of transformational leadership: a comparative analysis with traditional leadership styles. The Spanish Journal of Psychology, 10(2), 358-68. http://dx.doi.org/10.1017/S1138741600006624

Mowday, R. T., Porter, L. W., \& Steers, R. M. (1982). Employee-Organization Linkages: The Psychology of Commitment, Absenteeism and Turnover. New York: Academic Press.

National Oil Corporation. (2008). Gale directory of company histories. National Oil Corporation.

O’Driscoll, M. P., \& Randall, D. M. (1999). Perceived Organizational Support, Satisfaction with Rewards, and Employee Job Involvement and Organizational Commitment. Applied Psychology: An International Review, 48(2), 197-209. http://dx.doi.org/10.1111/j.1464-0597.1999.tb00058.x

Oluseyi, S. A., \& Ayo, H. T. (2009). Influence of Work Motivation, Leadership Effectiveness and Time Management on Employees' Performance in Some Selected Industries in Ibadan. European Journal of Economics, Finance and Administrative Sciences, 16, 7-17.

O'Reilly, C. A., \& Chatman, J. (1986). Organizational commitment and psychological attachment: The effects of compliance, identification and internalization on prosocial behavior. Journal of Applied Psychology, 71, 492-499. http://dx.doi.org/10.1037/0021-9010.71.3.492

Perryer, C., \& Jordan, C. (2005). The Influence of Leader Behaviors on Organizational Commitment, A Study in the Australian Public Sector. International Journal of Public Administration, 28, 379-396. http://dx.doi.org/10.1081/PAD-200055193

Porter, L. W., Steers, R. M., Mowday, R. T., \& Boulian, P. V. (1974). Organizational Commitment, Job Satisfaction, and Turnover among Psychiatric Technicians. Journal of Applied Psychology 59, 603-609. http://dx.doi.org/10.1037/h0037335

Rad, A. M. M., \& Yarmohammadian, M. H. (2006). A study of relationship between managers' leadership style and employees' job satisfaction. Leadership in Health Services, 19(2), 11-28. http://dx.doi.org/10.1108/13660750610665008

Ramey, J. W. (2002). The relationship between leadership styles of nurse managers and staff nurse job satisfaction in hospital settings. Huntington, West Virginia.: Marshall University.

Sasi, T. A. (2008). Antecedents of human resource management practices: Case study analyses of the National Oil Corporation in Libya. Doctoral dissertation, Tun Abdul Razak University. Kuala Lumpur.

Sekaran, U. (2005). Research methods for business: A skill building approach. India: Wiley.

Shahnawaz, M. G., \& Juyal, R. C. (2006). Human Resource Management Practices and Organizational Commitment in Different Organizations. Journal of the Indian Academy of Applied Psychology, 32(3), $171-178$.

Shawa, J. D., Deleryb, J. E., \& Abdulla, M. H. A. (2003). Organizational commitment and performance among guest workers and citizens of an Arab country. Journal of Business Research, 56, 1021-1030. http://dx.doi.org/10.1016/S0148-2963(01)00316-2

Shurbagi, A. A. M. (2014). The Relationship between Transformational Leadership and Organizational 
Commitment in National Oil Corporation of Libya. 3rd International Conference on Humanities, Biological and Environmental Sciences (pp. 99-105). Abu Dhabi, (UAE).

Shurbagi, A. A. M., \& Zahari, I. (2012). The effect of Organizational Culture and the Relationship between Transformational Leadership and Job Satisfaction in Petroleum Sector of Libya. International Business Research, 5(9), 89-97. http://dx.doi.org/10.5430/ijba.v4n4p26

Shurbagi, A. A. M., \& Zahari, I. (2013). The Relationship between Organizational Commitment and Job Satisfaction in National Oil Corporation of Libya. 2nd International Conference on Business, Economics, and Behavioural Sciences (pp. 17-23), Bali, (Indonesia).

Spector, P. E. (1985). Measurement of human service staff satisfaction: Development of the Job Satisfaction Survey. American Journal of Community Psychology, 13(6), 693-713. http://dx.doi.org/10.1007/BF00929796

Spector, P. E. (1997). Job satisfaction: Application, assessment, cause, and consequences. Sage Publications, Inc.

Suleiman, M. M. S., Azzawi, M. A. M., \& Jerjer, A. M. S. (2003). The impact of dimensions of transformational leadership in the management of organizational change. International Scientific Conference of the eighth annual Change management and knowledge society, Mosul, Iraq.

Wasti, S. A. (2005). Commitment profiles: Combinations of organizational commitment forms and job outcomes. Journal of Vocational Behaviour, 67, 290-308. http://dx.doi.org/10.1016/j.jvb.2004.07.002

Wiener, Y. (1982). Commitment in organizations: A normative view. Academy of Management Review, 7 , 418-428.

Williams, L. J., \& Hazer, J. T. (1986). Antecedents and consequences of satisfaction and commitment in turnover models: A reanalysis using latent variable structural equation methods. Journal of Applied Psychology, 71(2), 219-231. http://dx.doi.org/10.1037/0021-9010.71.2.219

Worrell, T. G. (2004). School psychologists's job satisfaction: ten years later of the Virginia Polytechnic Institute and State University doctoral dissertation Virginia Tech, Virginia.

Xenikou, A., \& Simosi, M. (2006). Organizational culture and transformational leadership as predictors of business unit performance. Journal of Managerial Psychology, 21(6), 566-579. http://dx.doi.org/10.1108/02683940610684409

Yiing, L. H., \& Zaman, A. K. (2009). The moderating effects of organizational culture on the relationships between leadership behavior and organizational commitment and between organizational commitment and job satisfaction and performance. Leadership and Organization Development Journal, 30(1), 53-86. http://dx.doi.org/10.1108/01437730910927106

Yousef, D. A. (1998). Correlates of perceived leadership style in a culturally mixed environment. Leadership \& Organization Development Journal, 19(5), 275-284. http://dx.doi.org/10.1108/01437739810234341

Yousef, D. A. (2000). Organizational commitment: a mediator of the relationships of leadership behaviour with job satisfaction and performance in a non-western country. Journal of Managerial Psychology, 15(1), 6-24. http://dx.doi.org/10.1108/02683940010305270

Yousef, D. A. (2001). Islamic work ethic: A moderator between organizational commitment and job satisfaction in a cross-cultural context. Personnel Review, 30(2), 152-169. http://dx.doi.org/10.1108/00483480110380325

\section{Copyrights}

Copyright for this article is retained by the author(s), with first publication rights granted to the journal.

This is an open-access article distributed under the terms and conditions of the Creative Commons Attribution license (http://creativecommons.org/licenses/by/3.0/). 